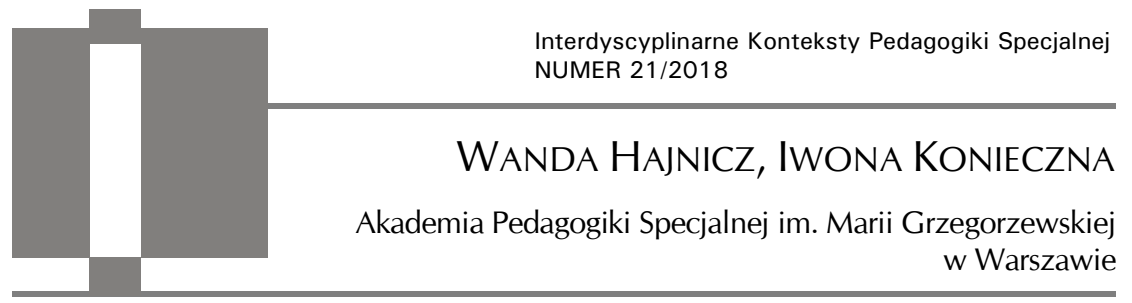

\title{
Otwarte problemy w obszarze pedagogiki leczniczej
}

Abstract: Wanda Hajnicz, Iwona Konieczna, Otwarte problemy w obszarze pedagogiki leczniczej [Opened problems in the area of healing pedagogy]. Interdyscyplinarne Konteksty Pedagogiki Specjalnej, nr 21, Poznań 2018. Pp. 263-278. Adam Mickiewicz University Press. ISSN 2300-391X. DOI: https:// doi.org/10.14746/ikps.2018.21.14

Recently, it has been noticed that the problems of specific specializations in the field of special education overlap or go far beyond the area of a given sub-discipline. The article addresses issues related to outlining the main problems that we may encounter in the area of pedagogy, and which are crucial for the lives of people with chronic illness in various areas of their functioning. They are: body traits - their importance in building identity in the situation of experiencing a chronic disease; coping with loss in a chronic disease situation; matching in contact with a person with a chronic illness and participation in social exchange.

KEY WORDS: healing pedagogy, chronic disease, body, identity, sense of control, resource, loss, coping, matching in contact, social exchange

Pedagogikę osób z chorobą przewlekłą tradycyjnie łączono z pedagogiką osób z niepełnosprawnością ruchową, określając te działania jako pedagogikę leczniczą. Aktualnie coraz częściej oddziela się od siebie te dwa ujęcia. Przede wszystkim z uwagi na fakt, że problemy, z jakimi borykają się osoby z chorobą przewlekłą, mają 
odmienny charakter ${ }^{1}$. Zadaniem pedagogiki leczniczej jest przede wszystkim wspieranie edukacyjne i podtrzymujące dzieci, młodzież i osoby dorosłe $\mathrm{z}$ chorobą przewlekłą, wkomponowane $\mathrm{w}$ ich proces leczenia.

Pedagogika osób z chorobą przewlekłą podejmuje m.in. kwestie związane z: wpływem choroby przewlekłej na funkcjonowanie jednostki w różnych obszarach życia, w tym wykorzystywanie działań edukacyjnych i podtrzymujących jako czynnika terapeutycznego, określa i dostosowuje działania edukacyjne do wydolności fizycznej i wysiłkowej osób z chorobą przewlekłą, przyczynia się do organizowania procesu edukacyjnego i podtrzymującego w miejscu pobytu osoby z chorobą oraz zapewnia wsparcie rodzinie osób z chorobą.

Warto podkreślić, iż pedagogika lecznicza ze względu na swój obszar zainteresowań, wykracza poza ścisły obręb pedagogiki specjalnej i łączy się problemowo z zagadnieniami dotyczącymi okresu starości.

W obszarze pedagogiki leczniczej można wyodrębnić zagadnienia wymagające pogłębienia teoretycznego i eksploracji badawczych. Dlatego też głównym celem artykułu jest dostarczenie nowych perspektyw - problemów w tym zakresie. Pragniemy poruszyć cztery problemy, w których możemy wyodrębnić dwie kategorie. Dwa z nich dotyczą bezpośrednio osoby borykającej się z doświadczaniem choroby przewlekłej i dwa odnoszą się do jej interakcji z innymi osobami.

Do pierwszej grupy można zaliczyć problemy odnoszące się do:

- cech ciała - ich znaczenia w budowaniu tożsamości w sytuacji doświadczania choroby przewlekłej,

- radzenia sobie ze stratą w sytuacji choroby przewlekłej.

Druga grupa problemów obejmuje:

- dopasowanie we wzajemnym kontakcie z osobą z chorobą przewlekłą,

- udział w wymianie społecznej osób z chorobą przewlekłą.

${ }^{1}$ A. Zawiślak, Wybrane zagadnienia z pedagogiki specjalnej, Oficyna Wydawnicza „Impuls”, Kraków 2009. 


\section{Cechy ciała - ich znaczenie w budowaniu tożsamości w sytuacji doświadczania choroby przewlekłej}

Ciało jest miejscem, w którym mamy szczęście lub nieszczęście przebywać. Stanowi źródło dobrego samopoczucia i przyjemności, ale jest także obiektem chorób i napięć. Nie jest tylko przedmiotem fizycznym, który każdy człowiek posiada. Stanowi układ działania oraz źródło praktyk, którego czynne zaangażowanie w codzienne interakcje jest niezbędne do zachowania spójnego poczucia siebie².

Każdy człowiek funkcjonuje w świecie w sposób "cielesny”. Osoba ludzka nie może funkcjonować poza ciałem. Funkcjonujemy w takiej rzeczywistości i tak ją poznajemy, jak nam na to powala nasze ciało. Ciało stanowi własność jednostki, co daje jej możliwość własnej kontroli, poczucie spójności cielesnej, ale i doświadczanie jej braku. Człowiek ma też pewną możliwość kształtowania swojego ciała, ale jest to związane z tym, że bierze on odpowiedzialność za "efekt”3.

Poczucie tożsamości cielesnej jest procesem gromadzenia indywidualnych doświadczeń związanych z własnym ciałem. Nieumiejętność nazywania własnych przeżyć, doznań, potrzeb, które płyną $\mathrm{z}$ ciała, powoduje liczne napięcia oraz wrażenie utraty orientacji w świecie osobistego doświadczenia. Zdolność modulowania siły własnych przeżyć oraz wiedza o przyczynach ich powstawania, przyczyniają się do kontroli nad samym sobą. Erving Goffman twierdzi, iż każdy kto przeżył momenty konfrontacji z niemożliwymi do zniesienia emocjami, szczególnie, gdy ich pojawienie było nieoczekiwane, zna poczucie alienacji wobec tych przeżyć. Ma także świadomość tego, czym jest poczucie spójności cielesnej i doświadczanie jej braku. Ciało nabiera szczególnego znaczenia w przypadku osób, u których jest ono „atakowane i naruszone” przez chorobę.

2 A. Giddens, Nowoczesność i tożsamość "Ja" i społeczeństwo w epoce późnej nowoczesność, PWN, Warszawa 2001, s. 137.

3 Z. Bauman, Ciało i przemoc w obliczu ponowoczesności, Wydawnictwo UMK, Toruń 1995, s. 192. 
Symboliczne interakcje pomiędzy pojęciem normalności $w$ odniesieniu do wyglądu ciała lub funkcji poszczególnych jego narządów wiązać się mogą z utratą znaczących atrybutów, prowadząc do naznaczenia, zgodnego $\mathrm{z}$ ujęciem prezentowanym przez Ervinga Goffmana.

W świetle założeń interakcjonizmu symbolicznego i badań Katarzyny Piątek możemy dokonać definicji kontroli ciała „kontrola i kierowanie ciałem są uzależnione od względnie autonomicznego ludzkiego podmiotu"4. W chorobie poczucie utraty kontroli nad własnym ciałem jest jedną z najważniejszych jej konsekwencji. Identyfikacja społeczna osoby z chorobą oddziałuje poprzez zmiany $\mathrm{w}$ ciele (ciało wyniszczone, ciało pozbawione pewnych organów wewnętrznych, niewidocznych) lub ciało $\mathrm{z}$ widocznymi, naznaczonymi chorobą i niepełnosprawnością zmianami lub okaleczenie w wyniku zastosowanej terapii. Temu może towarzyszyć poczucie zawstydzenia, skrępowania, zażenowania z powodu piętna choroby na ciele - stygmatyzacja.

Ciało zyskuje status zasobu, którym można zarządzać, przyczynia się do kreowania wersji "swojego ja” ${ }^{\prime 2}$. Znaczenia przypisywane ciału są wyznaczone przez skonwencjonalizowaną formę komunikacji niewerbalnej, nad którą jednostka nie ma kontroli, ale która wpływa na kategoryzację siebie i innych. Człowiek już od dziecka jest uczony tego, w jaki sposób prezentować swoje ciało $\mathrm{w}$ przestrzeni społecznej. Ciało, które nie spełnia pewnych „norm”, gdy nie ma nad nim kontroli, a zachowanie dla otoczenia nie jest jednoznaczne do interpretacji, podlega wykluczeniu 6 . To, jakie znaczenie człowiek przypisuje własnemu ciału, w dużej mierze jest warunkowane przez poznanie idiomatyki ciała, a nad którą człowiek z chorobą przewlekłą nie zawsze ma bezpośrednią kontrolę7.

${ }^{4}$ K. Piątek, Ciało nadzorowane. Strategie kontroli ciała podejmowane przez kobiety z niepetnosprawnością fizyczna, [w:] Fenomeny kontroli ciała, red. E. Banaszek, P. Czajkowski, R. Florkowski, Diffin, Warszawa 2012, s. 168.

5 C. Schilling, Socjologia ciała, PWN, Warszawa 2010.

${ }^{6}$ Ibidem.

${ }^{7}$ K. Piątek, op. cit., s. 168-169. 
Odwołując się do koncepcji ciała Ervinga Goffmana, należy zaznaczyć, iż jednostka, która podejmuje działania w społecznych granicach, ma pewne ograniczenia, które wpływają na jej autonomię. Katarzyna Piątek ${ }^{8} \mathrm{w}$ swoich badaniach $\mathrm{z}$ udziałem kobiet $\mathrm{z}$ niepełnosprawnością ruchową prezentuje je jako osoby mające potencjalnie jedyny wpływ na własną cielesność, ale będące zależnymi od społecznej kontroli. To ma związek ze stanowiskiem Chris'a Schillinga ${ }^{9}$, który twierdzi, iż ciało ludzkie charakteryzuje podwójne usytuowanie: jednostkowe (ujmowane jako własność każdej jednostki) i społeczne (definiowane i kontrolowane przez społeczeństwo) ${ }^{10}$.

Ciało odgrywa zatem ważną rolę $\mathrm{w}$ relacjach między tożsamością jednostki a tożsamością społeczną. Społeczna wartość przypisywana ciału jest przyjmowana przez jednostkę i ma udział w tworzeniu „ja” i kształtowaniu poczucia własnej wartości. Poczucie tożsamości społecznej budowanej za pośrednictwem ciała i koncepcja obrazu własnego ciała oznacza kontrolowanie własnej sytuacji życiowej poprzez skuteczność podejmowanych działań, mających podtrzymać lub zweryfikować dotychczasowe relacje społeczne ${ }^{11}$.

Zarządzanie ciałem odgrywa kluczową rolę w podtrzymywaniu relacji społecznych (włączanie się $\mathrm{w}$ przestrzeń społeczną przez osobę z chorobą przewlekłą) powoduje, iż wkracza ona w świat znaczeń i języka innych osób, funkcjonujących w nieco innej rzeczywistości. W takiej sytuacji ciało staje się "pośrednikiem” między tożsamością osobistą a społeczną.

Powyższe rozważania implikują problemy w obszarze pedagogiki leczniczej. Po pierwsze: na ile osoby z chorobą przewlekłą postrzegają swoje ciało jako element sprawczości i mają nad nim kontrolę, a także jakie stosują strategie kontroli dotyczące swojego

${ }^{8}$ K. Piątek, Ciało nadzorowane. Strategie kontroli ciała podejmowane przez kobiety z niepetnosprawnościa fizyczna, [w:] Fenomeny kontroli ciała, red. E. Banaszek, P. Czajkowski, R. Florkowski, Diffin, Warszawa 2012.

${ }^{9}$ C. Schilling, op. cit.

10 Ibidem.

${ }_{11}$ M.P. Kelly, D. Field, Medical sociology, chronic illness and the body, "Sociology of health and illness" 1996, 18, s. 241-257. 
ciała? Po drugie: $\mathrm{w}$ jaki sposób osoby $\mathrm{z}$ chorobą przewlekłą mają poczucie kontroli $w$ obrębie własnego ciała $\mathrm{i} w$ jakim stopniu ich decyzje dotyczące ciała są uzależnione od społecznej kontroli?

\section{Radzenie sobie ze stratą w sytuacji choroby przewlekłej}

W kontekście podejmowanych zagadnień problem straty jest kwestią fundamentalną. Osoba doświadczająca choroby przewlekłej, aby móc funkcjonować w sposób satysfakcjonujący w oparciu o posiadane zasoby, musi dać sobie radę z poczuciem straty.

Strata „to, co się przestało posiadać; też: fakt, że się przestało coś posiadać"12. Poczucie straty to stan emocjonalny pojawiający się w reakcji na wewnętrzne przekonanie o „braku”: przedmiotu, człowieka, możliwości. To emocja o nieprzyjemnym zabarwieniu, służąca uświadomieniu sobie potrzeby, którą trzeba zaspokoić innymi niż do tej pory (przed stratą) metodami13. Można tu wymienić różne rodzaje doświadczanych strat.

Strata może być postrzegana jako sytuacja, gdy czegoś ubyło, jest tego mniej w moim zasięgu. Może też być odbierana jako sytuacja pozbawienia, deficytu czegoś co było dostępne albo co jest dostępne innym, ale nie mnie. Strata może też być odczuwana jako nieobecność zniknięcie kogoś, czegoś znaczącego dla jednostki. Radzenie sobie z poczuciem straty jest związane nie tylko z jej przedmiotem (co zostało stracone), ale też ze sposobem jej odbierania, interpretowania, jej znaczenia.

Sytuacja utraty osoby (na skutek śmierci) pociąga za sobą trudny do zniesienia niepokój, rozpacz, poczucie bezradności, ryzyko utraty sensu i celu życia. Jest postrzegana jako strata nie do wyrównania związana z poczuciem zniknięcia, nieobecności zna-

12 Stownik Jezzyka Polskiego, red. L. Drabik, PWN, Warszawa 2006.

${ }^{13}$ G. Sędek, Jak ludzie radza sobie z sytuacjami, na które nie ma rady?, [w:] Złudzenia, które pozwalaja żyć. Szkice z psychologii społecznej, red. M. Kofta, T. Szustrowa, PWN, Warszawa 1991. 
czącej osoby. Reakcja na nią przybiera formę żałoby. Charakterystycznym zjawiskiem w tej sytuacji są reakcje ucieczki i powrotu do problemu, ale z mniejszą siłą emocji ${ }^{14}$.

W psychologii strata osoby utożsamiana jest z pojęciem żałoby. Żałoba to proces, co podkreślał już Zygmunt Freud. Erich Lindemann jako pierwszy mówiący o „przepracowywaniu straty”, zaznaczał jej zmienność i konieczność wydatkowania energii fizycznej i psychicznej, aby móc poradzić sobie z tym procesem. Żałoba to właśnie „przepracowywanie" uczuć, postaw, związków z osobą, której już nie ma15. Jej etapy i fazy są różnie nazywane i definiowane przez różnych autorów. Warto zwrócić uwagę w tym miejscu na model Franklina C. Shontza istotny dla wyjaśnienia reakcji na stratę bliskiej osoby. Model ten zakłada, iż pierwszą reakcją na śmierć jest szok. Osoby będące w tym stanie zachowują zadziwiającą przytomność myślenia i dużą sprawność w podejmowanych działaniach. „Dramat” nie dociera do nich, żyją w oderwaniu od rzeczywistości. Z doświadczaną bezradnością, dezorganizacją i przygnębieniem spotykają się po upływie czasu i wtedy konfrontują się z bólem, a to w znaczący sposób wpływa na pogorszenie poznawczego funkcjonowania. Nieustanne odczuwanie straty jest męczące. W związku z tym człowiek stara się nie myśleć o trudnym zdarzeniu, co prowadzi do sytuacji, w której stosuje wyparcie, doświadczając chwilowej poprawy swojego samopoczucia. W momencie pojawienia się trudnych emocji bywa, iż człowiek ma wielką trudność z radzeniem sobie z nimi, czego konsekwencją jest pojawienie się fazy wycofania ${ }^{16}$. Zdaniem Franklina C. Shontza zmienność następujących po sobie faz ma dobry wpływ na daną osobę, co z czasem pozwala na przystosowanie się do nowej sytuacji. Wraz z upływem czasu trudne emocje pojawiają się coraz rzadziej, co w efekcie pozwala na wyznaczanie nowych celów. Przechodzenie

${ }^{14}$ G. Sędek, Jak ludzie radza sobie z sytuacjami, na które nie ma rady?, [w:] Złudzenia, które pozwalaja żyć. Szkice z psychologii społecznej, red. M. Kofta, T. Szustrowa, PWN, Warszawa 1991, s. 289-319.

15 A. Ostrowska, Śmierć w doświadczeniu jednostki i społeczeństwa, Wydawnictwo IFIS PAN, Warszawa 1997.

16 Ibidem, s. 289-319. 
pomiędzy fazami konfrontacji i odwrotu, nie ma charakteru nieprzystosowawczego. Jest koniecznym warunkiem rozwoju'17.

Inny rodzaj doświadczanej straty może mieć charakter straty w kontekście utraty rzeczy. W tym przypadku możemy mieć do czynienia z różnymi sposobami interpretowania takiej sytuacji. Sposób jej interpretowania zależy od skali straty i znaczenia dla naszego dobrostanu utraconych rzeczy. Gdy zostają utracone środki umożliwiające zaspokojenie podstawowych potrzeb życiowych, możemy mieć poczucie ich zaniku, nieistnienia i doświadczać traumy. W innych przypadkach, mniejszej skali możemy doświadczać pozbawienia, łączącą się z nim nieodwracalnością utraty albo też postrzegamy daną stratę jako pewien ubytek, zmniejszenie pewnych zasobów. Radzenie sobie z tą sytuacją ma przede wszystkim charakter pragmatyczny, wsparcie materialne i instrumentalne, pozwalające na zmniejszenie kosztów ubytku. Jedną z form radzenia sobie $\mathrm{z}$ tym rodzajem straty jest przekształcanie tego doświadczenia w temat, który stanowi podstawę kontaktów z innymi (opowieść o...). Rozważanie także tego w kontekście tego, co ta sytuacja dała osobie jej doświadczającej, czego ją nauczyła. Jakie doświadczenia z tej sytuacji może człowiek wyciągnąć dla siebie oraz co może zrobić w związku z tą stratą (uruchamianie strategii radzenia sobie $\mathrm{z}$ tą stratą i minimalizowanie jej kosztów). Ten rodzaj straty ma charakter doświadczania straty „z zewnętrz” w wyniku sytuacji losowej, której dana osoba nie była w stanie uniknąć.

Choroba przewlekła zarówno na początku, jak i w miarę jej postępu wiąże się z tym, iż osoba doświadcza straty w obrębie siebie: traci sprawność, zdolności w zakresie funkcjonowania ciała, autonomii, samorealizacji i realizacji ról społecznych. Doświadczane straty mogą być bardzo poważne i odnosić się do istotnych aspektów funkcjonowania ciała prowadząc nawet do jego całkowitej niesprawności.

17 B. Dobrzańska-Socha, Pomoc psychologiczna w sytuacji straty, [w:] Zmagając się $z$ choroba nowotworowa. Psychologia wspótczesna wobec pacjentów onkologicznych, red. D. Kubacka-Jasiecka, W. Łosiak, Wydawnictwo Uniwersytetu Jagiellońskiego, Kraków 1999, s. 289-340. 
Strata $\mathrm{w}$ obrębie siebie $\mathrm{w}$ sytuacji choroby przewlekłej jest najtrudniejszą stratą, ponieważ jednostka ma świadomość trudności jej zastąpienia. Strata $\mathrm{w}$ wymiarze utraty zdrowia powoduje, że jednostka doświadcza zmniejszenia poczucia własnych możliwości.

Proces pogodzenia się ze stratami życia z poczuciem i rozwijania się $\mathrm{w}$ granicach wyznaczanych poprzez chorobę nigdy dla człowieka nie jest łatwy i bezbolesny. Do poczucia straty dołącza się często poczucie przegranej, co powoduje, że dodatkowo strata jest wartościowana i cały ten ciężar wydaje się być rzeczywiście nie do wytrzymania. Wśród strat poniesionych $\mathrm{w}$ wyniku choroby przewlekłej są takie straty z którymi nie sposób do końca się pogodzić. Jak pisze Silvia Bonino:

ciężkie straty są jak rany, stanowiące część nas samych, z którymi musimy nauczyć się żyć i w których istnieniu trzeba znaleźć powód do wewnętrznego rozwoju, mimo, że te rany mogą się czasem otwierać, boleć i nadal krwawić ${ }^{18}$.

Proces straty w obrębie siebie nie jest tożsamy z doświadczaniem żałoby. Może być traktowany jako żałoba, ale musi zostać przez daną osobę przepracowany.

Starta $\mathrm{w}$ obrębie siebie przybiera jeszcze inny charakter, kiedy mamy do czynienia z chorobą nabytą, a nie wrodzoną. Człowiek wówczas dokonuje porównania z tego, co było dla niego wcześniej dostępne i możliwe w różnych obszarach jego życia. Wraz z pojawieniem się choroby traci swoje wcześniejsze możliwości, a przy chorobie o charakterze postępującym ma też świadomość przyszłych, kolejnych strat.

Człowiek w chorobie doświadcza straty w sposób nieodwracalny. Zastanawiając się nad zjawiskiem poczucia straty związanym z chorobą przewlekła warto zwrócić uwage na to, że akceptacja choroby może nastąpić po uporaniu się ze stratą w obrębie siebie. W związku z tym pojawiają się pytania: $W$ jakim kontekście strata w obrębie siebie ma charakter mobilizujący do działania, a w jakim

18 S. Bonino, Tysiace nici mnie tu wiąże, Wydawnictwo APS, Warszawa 2008, s. 66. 
staje się stratą o charakterze demobilizującym, ze szczególnym uwzględnieniem dynamiki danego procesu chorobowego? Jakie strategie są stosowane przez osoby $\mathrm{z}$ chorobą przewlekłą $\mathrm{w}$ celu radzenia sobie, ze szczególnym uwzględnieniem dynamiki danego procesu chorobowego? Czy i na ile strata w obrębie siebie doświadczana przez osoby z chorobą przewlekłą może stać się tematem $\mathrm{w}$ kontaktach $\mathrm{z}$ innymi osobami, z kim i w jakim celu?

\section{Dopasowanie we wzajemnym kontakcie z osobą z chorobą przewlekłą}

Na początku omawiania wybranych problemów w obszarze pedagogiki leczniczej zaakcentowana została kwestia tego, że nasze ciało wyznacza nam rzeczywistość, w której funkcjonujemy. W związku z tym człowiek może doświadczać pewnego dysonansu między swoją świadomością dotyczącą rzeczywistości i możliwości funkcjonowania $\mathrm{z}$ ciałem $\mathrm{w}$ tej rzeczywistości (albo z informacji z zewnątrz - widzimy innych albo $z$ własnego doświadczenia sprzed choroby).

Można zatem uznać, iż osoba $\mathrm{z}$ chorobą przewlekłą musi dawać sobie radę z sytuacją dysonansu. Jeżeli jednostka odrzuca sytuację dysonansu to może stosować pewne formy buntu, biernego (oporu) lub czynnego, walki z przeciwnościami lub z otoczeniem. Refleksyjne „przepracowywać” dysonansy pozwala na podjęcie prób dopasowywania się do konkretnych sytuacji, może to stanowić istotny czynnik $w$ procesie przystosowywania się.

Zjawisko dopasowania występuje w dwóch postaciach: (1) dopasowanie działań do warunków zewnętrznych (przedmioty tworzone przez człowieka nabierają ergonomicznych kształtów dopasowanych do jego działań motorycznych); (2) w interakcji polegające na świadomości sygnałów i komunikatów płynących od osoby, z którą współdzielimy określone działanie ${ }^{19}$.

${ }^{19}$ H.R. Schaffer, Wzajemność kontroli we wczesnym dzieciństwie, [w:] Dziecko w świecie ludzi i przedmiotów, red. A. Brzezińska i G. Lutomski, Wydawnictwo Zysk i S-ka, Poznań 1994, s. 130-131. 
Problem dopasowania występuje także w komunikacji werbalnej (w obszarze komunikacji partnerskiej). Często wymagamy od osoby, z którą wchodzimy w kontakt określonego zachowania. Wręcz domagamy się, by umiała funkcjonować w ramach określonego schematu i wpisywała się stereotypowo w tworzone dla określonej sytuacji ramy. Kiedy np. nasz współrozmówca ze względu na swoje cechy lub zasoby zachowuje się niestandardowo, wówczas próbujemy „dopasować się" do niego.

Dbanie o zaspokojenie własnych potrzeb we wzajemnym kontakcie jest niezwykle ważne $\mathrm{w}$ perspektywie komunikacyjnej. $\mathrm{W}$ relacjach obu partnerów o zróżnicowanych możliwościach komunikacyjnych zawsze każdy z nich powinien zachować swoją jednostkowość i mieć świadomość swoich potrzeb i racji. Jednak może być to bardzo utrudnione, kiedy ze względu na porozumiewanie się według różnych kodów językowych ograniczone jest wzajemne porozumienie bądź jedna ze stron doświadcza uzależnienia od drugiej. Stosowanie odmiennego słownictwa czy też ujawnianie innego stylu prowadzenia rozmowy może zdecydować o niepowodzeniu danej sytuacji, bez świadomej winy współrozmówców. Dzieje się tak, gdyż każdy z nich komunikuje się według znanego sobie schematu, stosując tym samym własne strategie porozumiewania się, nie uwzględniając w nich perspektywy współrozmówcy.

Dopasowanie w literaturze występuje przede wszystkim przy analizowaniu działań osoby opiekującej się małym dzieckiem - im młodszym tym bardziej wyraziste dopasowanie jest zauważane; w przypadku osób dorosłych zwraca się przede wszystkim uwagę na problemy wynikające $\mathrm{z}$ braku dopasowania prowadzące do depersonalizacji. Szerzej to zjawisko jest omawiane w kontekście instytucji totalnych ${ }^{20}$ W relacji opieki dopasowywanie jest ukryte w specyficznym dookreśleniu pojęcia troski. Określenie to bardzo często traktowane jest jako synonim pojęcia opieka, ale w swojej

${ }^{20}$ E. Tarkowska, Ludzie w instytucji totalnej. Przypadek domów pomocy społecznej w Polsce, [w:] Upośledzenie w społecznym zwierciadle, red. A. Gustavsson, E. Zakrzewska-Manterys, Wydawnictwo ŻAK, Warszawa, 1997. 
monografii Judith Phillips stara się niuansować te pojęcia, wskazując na ładunek emocjonalny zawarty w pojęciu troska. Przytacza tam takie oto określenie czym jest troska: „wyjście poza własne ego ponieważ nie tylko go nie dotyczy, ale również o nim zapomina. Prócz tego troska pośrednio zakłada działanie"21. Ponadto autorka podkreśla, że troska może być postrzegana jako pojęcie holistyczne przenikające wszelkie relacje i działania ludzkie. Tak rozumiejąc to pojęcie, możemy rozróżnić opiekę, jako działanie wspomagające $\mathrm{w}$ realizacji potrzeb drugiej osoby, których ona sama nie może zaspokoić oraz opiekę troskliwą, w której uwidacznia się kontekst emocjonalny takich działań prowadzący do dbałości o dobrostan osoby obdarzanej opieką.

Można zauważyć, że w takim rozumieniu pojęcia troski wyraziściej akcentowane jest zjawisko dopasowania. Ujawnia się ono $\mathrm{w}$ obu znaczeniach $\mathrm{w}$ pierwszym, mówiącym o odpowiedniości działań do warunków zewnętrznych, a szczególnie w drugim mówiącym o świadomości sygnałów i komunikatów płynących od osoby, z którą współdzielimy określone działanie. W tym miejscu ujawnia się bardzo istotne zagadnienie współdzielenia troski, troska dotyczy osoby wspieranej. Osoba wspierająca troszczy się o nią, gdy realizując określone działania wspierające, zwraca uwagę na sygnały i komunikaty podnoszące lub zagrażające dobrostanowi osoby, której udziela pomocy czy opieki. Relacja troski jest jednak współzależna. Ważna jest również troska osoby wspieranej o tego, któremu udziela pomocy, wyraża się różnego rodzaju zachowaniami, ujawniającymi aktywny współudział we współdzielonym działaniu.

Powyższe analizy implikują określone problemy dla pedagogiki leczniczej: Jakie koszty są związane z procesem dopasowania działań w ramach interakcji osób w niej uczestniczących? Jak określać granice możliwości dopasowania działań w ramach interakcji mających charakter pomocy? Jakie skutki powoduje brak dopasowania $\mathrm{w}$ interakcji, szczególnie w sytuacji udzielania pomocy?

${ }^{21}$ J. Pillips, Troska, Wydawnictwo SIC!, Warszawa 2009, s. 24-25. 


\section{Udział w wymianie społecznej osób z chorobą przewlekłą}

Wymiana społeczna (ang. social exchange) to $\mathrm{w}$ socjologii proces wymiany dóbr i usług pomiędzy co najmniej dwiema osobami, prowadzący do nawiązywania trwałych znajomości i ustanawiania zwierzchnictwa nad innymi ${ }^{22}$. Jest też traktowana szeroko - interakcja jako wymiana ${ }^{23}$. Wymiana jest jednym ze sposobów, w jaki osoby tworzą i umacniają organizację społeczną. W takim ujęciu wymiana jest dla tych osób bardzo ważnym źródłem porządku społecznego, który powstaje jako nieplanowany rezultat aktów wymiany między członkami społeczeństwa. Wymiana staje się swoistą dobrowolną transakcją, polegając na przekazywaniu różnego rodzaju dóbr między dwoma lub więcej osobnikami, z czego wszyscy zyskują wzajemną korzyść. Przy czym przekazywane dobra mają charakter materialny, jak i niematerialny (uznanie społeczne, prestiż oraz wartość tego, co jest przypisywane w danej grupie ${ }^{24}$. Dla George'a C. Homansa interakcja społeczna ma miejsce wtedy, gdy "aktywność jednego człowieka zostaje nagrodzona lub ukarana przez innego" 25 . $\mathrm{W}$ takim ujęciu udział $\mathrm{w}$ interakcji społecznej wiąże się z przeświadczeniem, że dobra cenione przez jednego człowieka lub mu niezbędne są w posiadaniu innych ludzi, którzy dzięki temu mogą go nagradzać. Aby ich do tego zachęcić, należy coś im ofiarować w postaci dobra lub jakiejś usługi. W ten sposób tworzona jest sieć społeczna.

Istotą funkcjonowania w sieci społecznej jest wymiana społeczna. Wymiana społeczna jest konstruktem, który buduje trwałość. Jeśli chodzi o wymianę społeczną obowiązuje w jej ramach zasada wzajemności ${ }^{26}$. Można zauważyć, iż wymiana i obowiązująca w jej ramach zasada wzajemności są mechanizmem budowania sieci

22 P. Blau, Wymiana spoteczna, [w:] Socjologia. Lektury, red. P. Sztompka, M. Kucia, Wydawnictwo Znak, Kraków 2005.

${ }^{23}$ G.C. Homans, The nature of social science, University Press, New York 1967.

${ }^{24}$ B. Szacka, Wprowadzenia do socjologii, Wydawnictwo Oficyna Naukowa, Warszawa 2003, s. 124.

${ }^{25}$ Ibidem, s. 124.

${ }^{26}$ C. Lévi-Strauss, Zasada wzajemności, [w:] Wspótczesne teorie wymiany społecznej. Zbiór tekstów, red. M. Kempny, J. Szmatka, PWN, Warszawa 1992. 
społecznej. Im bardziej osoba uczestniczy w wymianie, tym bardziej jest „umocowana" w sieci społecznej.

W tym kontekście należy odnieść się do pojęcia wsparcia społecznego, które jest konsekwencją przynależności człowieka do sieci społecznej27. Wsparcie społeczne może być opisywane jako rodzaj interakcji społecznej, która została podjęta przez jednego lub kilku uczestników sytuacji problemowej, trudnej, stresowej lub krytycznej. $W$ toku tej interakcji ma miejsce przekazywanie lub wymiana emocji, informacji, instrumentów działania i dóbr materialnych. Wymiana ta może być jednostronna lub dwustronna zaś jej kierunek stały lub zmienny. Warto podkreślić, iż w określonym układzie interakcji można wyróżnić osobę wspierającą, poszukującą wsparcia, odbierającą lub otrzymującą wsparcie. Dla skuteczności tej wymiany społecznej niezwykle ważna jest odpowiedzialność między rodzajem i zakresem udzielanego wsparcia, a także potrzebami odbiorcy - osoby z chorobą przewlekłą ${ }^{28}$.

Funkcjonalne cechy wsparcia stanowią podstawę jego podziału na wsparcie spostrzegane i wsparcie otrzymywane. Wsparcie spostrzegane przede wszystkim wynika z wiedzy i przekonań człowieka z chorobą o tym, gdzie i od kogo może uzyskać pomoc, na kogo może liczyć $\mathrm{w}$ trudnej, stresowej sytuacji. W tym rodzaju wsparcia dokonuje się oceny przekonań danej osoby o dostępności sieci. Natomiast wsparcie otrzymywane jest oceniane obiektywnie lub relacjonowane subiektywnie przez odbiorcę jako faktycznie otrzymywany rodzaj i ilość wsparcia. Spostrzegane i otrzymywane wsparcie zależy od kontekstu sytuacji trudnej, a także potrzeb osób z chorobą przewlekłą i cech sieci społecznych dostępnych i wykorzystywanych w określonych sytuacjach. Interakcje wsparcia oraz skuteczność ich działania są w znacznym stopniu uwarunkowane właściwościami osoby wspieranej. Zależą one od jej zasobów osobistych, zasobów struktury ,ja", samooceny,

27 J. Pommersbach, Wsparcie społeczne a choroba, "Przegląd Psychologiczny", $1988,31,2$, s. 503-525.

${ }^{28}$ H. Sęk, R. Cieślak, Wsparcie społeczne - sposoby definiowania, rodzaje i źródła wsparcia, wybrane koncepcje teoretyczne, [w:] Wsparcie spoleczne, stres $i$ zdrowie, red. H. Sęk, R. Cieślak, PWN, Warszawa 2006, s. 18. 
poczucia kontroli, kompetencji społecznych oraz jej pozycji społecznej. Biorąc pod uwagę cechy osoby z chorobą przewlekłą (osoby wspieranej), należy wskazać na potrzeby wsparcia społecznego jako stałe właściwości. Mogą one mieć charakter obiektywny biorąc pod uwagę wiek i położenie społeczne, wpływające na samodzielne radzenie sobie $\mathrm{z}$ trudnościami lub stanowić cechę osobowości zależnej. Niewielkie nasilenie potrzeb wsparcia oraz ich ujawniania jest spotykane u osób z silną potrzebą autonomii i niezależności ${ }^{29}$.

Jeżeli wsparcie nie jest dostrzegane przez osobę z chorobą przewlekłą, to można uznać, iż jest ono korzystniejsze dla jednostki. Przede wszystkim dlatego, że jeśli człowiek ma świadomość wsparcia, to ma to wpływ na jego samoocenę. Skutkiem zaniżenia samooceny jest ujawnianie określonych sposobów odzyskiwania kontroli nad sytuacją (przykład - postawa roszczeniowa). Dlatego też udział w wymianie społecznej jest konieczny dla poczucia dobrostanu osoby z chorobą przewlekłą przede wszystkim po to, aby doświadczać poczucia kontroli nad sytuacją.

Zatem pojawiają się kluczowe pytania: jak udzielać wsparcia, $\mathrm{w}$ tym wsparcia pedagogicznego osobom z chorobą przewlekłą, żeby umacniać ich możliwości w wymianie społecznej? oraz: jak udzielać wsparcia osobom z chorobą przewlekłą, aby ułatwiać im uczestniczenie w niesymetrycznej wymianie społecznej?

Przedstawione w ramach poszczególnych obszarów pytania problemowe stanowią otwarte zagadnienia wymagające dalszych eksploracji badawczych z uwagi na to, iż mają kluczowe znaczenie dla życia osób z chorobą przewlekłą w różnych obszarach ich funkcjonowania.

\section{Bibliografia}

Bauman Z., Ciało i przemoc w obliczu ponowoczesności, Wydawnictwo UMK, Toruń 1995. Blau P., Wymiana społeczna, [w:] Socjologia. Lektury, red. P. Sztompka, M. Kucia, Wydawnictwo Znak, Kraków 2005.

${ }^{29}$ Ibidem, s. 21. 
Bonino S., Tysiace nici mnie tu wiąże, Wydawnictwo APS, Warszawa 2008.

Dobrzańska-Socha B., Pomoc psychologiczna w sytuacji straty, [w:] Zmagajac się $z$ choroba nowotworowa. Psychologia wspótczesna wobec pacjentów onkologicznych, red. D. Kubacka-Jasiecka, W. Łosiak, Wydawnictwo Uniwersytetu Jagiellonskiego, Kraków 1999.

Giddens A., Nowoczesność i tożsamość "Ja" i społeczeństwo w epoce późnej nowoczesność, PWN, Warszawa 2001.

Homans G.C., The nature of social science, University Press, New York 1967.

Kelly M.P., Field D., Medical sociology, chronic illness and the body, "Sociology of health and illness" 1996, 18.

Lévi-Strauss C., Zasada wzajemności, [w:] Wspótczesne teorie wymiany społecznej. Zbiór tekstów, red. M. Kempny, J. Szmatka, PWN, Warszawa 1992.

Ostrowska A., Śmierć w doświadczeniu jednostki $i$ społeczeństwa, Wydawnictwo IFIS PAN, Warszawa 1997.

Pillips J., Troska, Wydawnictwo SIC!, Warszawa 2009.

Piątek K., Ciało nadzorowane. Strategie kontroli ciała podejmowane przez kobiety z niepetnosprawnościa fizyczna. [w:] Fenomeny kontroli ciała, red. E. Banaszek, P. Czajkowski, R. Florkowski, Diffin, Warszawa 2012.

Pommersbach J., Wsparcie społeczne a choroba , Przegląd Psychologiczny” 1988, 31, 2.

Schaffer H.R., Wzajemność kontroli we wczesnym dzieciństwie, [w:] Dziecko w świecie ludzi i przedmiotów, red. A. Brzezińska, G. Lutomski, Wydawnictwo Zysk i S-ka, Poznań 1994.

Schilling C., Socjologia ciała, PWN, Warszawa 2010.

Sędek G., Jak ludzie radza sobie z sytuacjami, na które nie ma rady?, [w:] Złudzenia, które pozwalaja żyć. Szkice z psychologii społecznej, red. M. Kofta, T. Szustrowa, PWN, Warszawa 1991.

Sęk H., Cieślak R., Wsparcie społeczne - sposoby definiowania, rodzaje i źródła wsparcia, wybrane koncepcje teoretyczne, [w:] Wsparcie społeczne, stres i zdrowie, red. H. Sęk, R. Cieślak, PWN, Warszawa 2006.

Stownik Jezzyka Polskiego, red. L. Drabik, PWN, Warszawa 2006.

Szacka B., Wprowadzenia do socjologii, Wydawnictwo Oficyna Naukowa, Warszawa 2003.

Tarkowska E., Ludzie w instytucji totalnej. Przypadek domów pomocy społecznej w Polsce, [w:] Upośledzenie w społecznym zwierciadle, red. A. Gustavsson, E. Zakrzewska-Manterys, Wydawnictwo ŻAK, Warszawa, 1997.

Zawiślak A., Wybrane zagadnienia z pedagogiki specjalnej, Oficyna Wydawnicza „Impuls", Kraków 2009. 